\title{
In vitro susceptibility of nematophagous fungi to antiparasitic drugs: interactions and implications for biological control
}

\author{
J. N. Vieira ${ }^{*}$, F. S. Maia Filho ${ }^{a}$, G. F. Ferreira ${ }^{b}$, J. F. Mendes ${ }^{b}$, C. L. Gonçalves ${ }^{a}$, \\ M. M. Villela ${ }^{a}$, D. I. B. Pereira ${ }^{a}$ and P. S. Nascente
}

aPrograma de Pós-graduação em Parasitologia, Departmento de Microbiologia e Parasitologia, Instituto de Biologia, Universidade Federal de Pelotas - UFPel, Campus Capão do Leão, s/n, CEP 96001-970, Capão do Leão, RS, Brazil ${ }^{\text {b}}$ Departamento de Veterinária Preventiva, Centro de Diagnóstico e Pesquisa Veterinária, Faculdade de Veterinária, Universidade Federal de Pelotas - UFPel, Campus Capão do Leão, s/n, CEP 96001-970, Capão do Leão, RS, Brazil

*e-mail: jujununesvieira@yahoo.com.br

Received: October 2, 2015 - Accepted: April 6, 2016 - Distributed: August 31, 2017

\begin{abstract}
The fast anthelmintic resistance development has shown a limited efficiency in the control of animal's endoparasitosis and has promoted research using alternative control methods. The use of chemicals in animal anthelmintic treatment, in association with nematophagous fungi used for biological control, is a strategy that has proven to be effective in reducing the nematode population density in farm animals. This study aims to verify the in vitro susceptibility of the nematophagous fungi Arthrobotrys oligospora, Duddingtonia flagrans and Paecilomyces lilacinus against the antiparasitic drugs albendazole, thiabendazole, ivermectin, levamisole and closantel by using the Minimum Inhibitory Concentration (MIC). MICs ranged between 4.0 and $0.031 \mu \mathrm{g} / \mathrm{mL}$ for albendazole, thiabendazole and ivermectin, between 0.937 and $0.117 \mu \mathrm{g} / \mathrm{mL}$ for levamisole, and between 0.625 and $0.034 \mu \mathrm{g} / \mathrm{mL}$ for closantel. The results showed that all antiparasitic drugs had an in vitro inhibitory effect on nematophagous fungi, which could compromise their action as agents of biological control. D. flagrans was the most susceptible species to all drugs.
\end{abstract}

Keywords: nematophagous fungi, benzimidazoles, ivermectin, levamisole, closantel.

\section{Suscetibilidade in vitro de fungos nematófagos à antiparasitários: interações e implicações para o controle biológico}

\section{Resumo}

O desenvolvimento rápido da resistência anti-helmíntica demonstrou a eficiência limitada no controle de endoparasitoses em animais, e promoveu a investigação em métodos de controles alternativos. $\mathrm{O}$ uso de produtos químicos no tratamento anti-helmíntico animal, em associação com fungos nematófagos utilizados para o controlo biológico, é uma estratégia que tem provado ser eficaz na redução da densidade da população de nematódeos em animais agrícolas. Este estudo teve como objetivo verificar a suscetibilidade in vitro dos fungos nematófagos Arthrobotrys oligospora, Duddingtonia flagrans e Paecilomyces lilacinus frente aos antiparasitários albendazol, tiabendazol, ivermectina, levamisol e closantel, usando a concentração inibitória mínima (MIC). Os MICs variaram entre 4,0 e 0,031 $\mu \mathrm{g} / \mathrm{mL}$ para albendazol, tiabendazol e ivermectina, entre 0,937 e $0,117 \mu \mathrm{g} / \mathrm{mL}$ para o levamisol, e entre 0,625 e $0,034 \mu \mathrm{g} / \mathrm{mL}$ para closantel. Os resultados mostraram que todos os antiparasitários tiveram um efeito inibidor in vitro sobre os fungos nematófagos, o que poderia comprometer suas atividades como agentes de controle biológico. $D$. flagrans foi a espécie mais sensível a todas as drogas.

Palavras-chave: fungos nematófagos, benzimidazóis, ivermectina, levamisol, closantel.

\section{Introduction}

Gastrointestinal helminths are one of the major conditions that interfere with the full development of the livestock industry (Mota et al., 2003), causing relevant damage, as they can lead to a delay in animal development, management overspending, reduced herd productivity, increased economic losses and, ultimately, death (Caracostantogolo et al., 2013). The widespread use of anthelmintics has restricted the use of most chemicals, as evidenced by the occurrence of resistance, food residues and ecotoxic action (Cezar et al., 2008). These drawbacks have spurred the search for alternative control methods which can complement / reduce anthelmintic 
use in endoparasitoses control strategies in pasture-based production systems (Saumell et al., 2008). In that context, biological control using nematophagous fungi appears as a promising strategy which can produce satisfactory results (Braga et al., 2008; Saumell et al., 2015).

Nematophagous fungi are nematode natural enemies. These fungi parasite the eggs and larvae of the geohelminthes living outside hosts and can be used to reduce the level of environmental contamination (Braga et al., 2007). They can capture or even kill the parasite, and are classified as endoparasites, predators or opportunistic (ovicidal) (Braga et al., 2008). Predatory fungi of the genera Arthrobotrys spp., Duddingtonia spp. and Monacrosporium spp. have proved to be effective as laboratory and field nematode biological control agents (Mota et al., 2003; Braga et al., 2011; Saumell et al., 2015). Among ovicidal fungi, Pochonia chlamydosporia and Paecilomyces lilacinus stand out and have been extensively studied in relation to their ovicidal activity on Toxocara canis and other geohelminthes (Carvalho et al., 2010). Within the group of endoparasites, studies showed that Drechmeria coniospora and Harposporium anguillulae can be able to significantly reduce infectious larvae of Haemonchus contortus (Jansson et al., 1985; Santos and Charles, 1995; Charles et al., 1996).

The advantage of combining nematophagous fungi biological control with chemical control is that the former acts on the infective forms present in the stools, whereas the latter acts on gastrointestinal nematodes that parasite the animal. However, some studies have shown that the combined use of incompatible pesticides in integrated pest management may inhibit the development and reproduction of entomopathogenic fungi (Neves et al., 2001; Alizadeh et al., 2007). In this context, in vitro experiments have been conducted to verify the effect of chemicals on entomopathogenic fungi, demonstrating the influence of these chemicals on fungus viability (Barci et al., 2009). Nevertheless, only Sanyal et al. (2004) and Singh et al. (2010) reported in vivo tests analyzing the compatibility of nematophagous fungi with regularly used antiparasitic formulations.

The lack of compatibility studies with nematophagous fungi, as well as the lack of a standardized method for in vitro test, has prompted the development of this research, which aimed to check the in vitro activity of drugs prescribed for animal anthelmintic treatment on the fungi growth used in parasite biological control.

\section{Material and Methods}

\subsection{Sample acquisition}

The antiparasitic drugs albendazole, thiabendazole, ivermectin, levamisole and closantel were commercially purchased from manufacturers, and the nematophagous fungi Arthrobotrys oligospora, Duddingtonia flagrans and Paecilomyces lilacinus, were kindly provided by CENARGEN - Centro Nacional de Pesquisa de Recursos Genéticos e Biotecnologia (National Research Center for
Genetic Resources and Biotechnology) - EMBRAPA. The fungi were kept in tubes containing Potato Dextrose Agar (PDA) at environment temperature $\left(25^{\circ} \mathrm{C}\right)$, recommended for maintenance of filamentous fungi according to the Clinical and Laboratory Standards Institute (CLSI, 2008).

\subsection{Susceptibility testing}

The susceptibility test was performed by using the broth micro dilution technique, according to reference document M38-A2 recommended to filamentous fungi by the Clinical and Laboratory Standards Institute (CLSI, 2008), adapted for antiparasitic drug testing. This test evaluates the growth, or not, of each fungi against each different drug concentrations.

Ten successive dilutions (1:2) were prepared from the stock solution for each drug, according with the commercial indicated concentration by each fabricant. Each antiparasitic was diluted in RPMI-1640 broth at concentrations ranging from 4.0 to $0.0078 \mu \mathrm{g} / \mathrm{mL}$ for albendazole, thiabendazole and ivermectin, from 1.875 to $0.003 \mu \mathrm{g} / \mathrm{mL}$ for levamisole and from 2.5 to $0.004 \mu \mathrm{g} / \mathrm{mL}$ for closantel. One hundred $\mu \mathrm{L}$ aliquots for each concentration of antiparasitic drug were dispensed into corresponding well microplates; a $100 \mu \mathrm{L}$ inoculum solution prepared from the conidial suspension of the fungus in sterile saline and adjusted to a 68 to $70 \%$ transmittance $\left(0.4 \times 10^{4}\right.$ to $\left.5 \times 10^{4} \mathrm{UFC} / \mathrm{mL}\right)(\mathrm{CLSI}$, 2008 ) was added to each well. The negative control was composed of at least $200 \mu \mathrm{L}$ of RPMI-1640 broth without anti-helminthic drug, and the positive control, composed by $100 \mu \mathrm{L}$ of RPMI-1640 without anti-helminthic drug and $100 \mu \mathrm{L}$ of the fungal inoculum. The plates were incubated at $25^{\circ} \mathrm{C}$ for $48 \mathrm{~h}$. All tests were performed in duplicate with three repetitions.

\subsection{Minimum Inhibitory Concentration (MIC) reading}

Fungus growth in the wells containing the different concentrations tested was visually compared with its growth in the positive control well for the test reading. The smallest concentration able to inhibit fungus growth in relation to the positive control well was identified as the MIC (Minimum Inhibitory Concentration) of the drug for that sample.

\section{Results}

The MICs of the different drugs tested against nematophagous fungi are shown in Table 1.

D. flagrans showed the highest sensitivity to the antiparasitic drugs tested, with albendazole showing the lowest MIC $(0.031 \mu \mathrm{g} / \mathrm{mL})$. A. oligospora showed the highest susceptibility to thiabendazole (MIC $0.125 \mu \mathrm{g} / \mathrm{mL}$ ), and $P$. lilacinus the highest susceptibility to closantel $(0.312 \mu \mathrm{g} / \mathrm{mL})$.

\section{Discussion}

The biological control by means of nematophagous fungi is being exploited and tested out in almost all parts of the world, under various climatic conditions and production 
Table 1. Minimal Inhibitory Concentrations $(\mu \mathrm{g} / \mathrm{mL})$ of five antiparasitic drugs against three nematophagous fungi, in vitro.

\begin{tabular}{lccccc}
\hline \multicolumn{1}{c}{ Antiparasitic drugs } & \multirow{2}{*}{ ivermectin } & albendazole & thiabendazole & levamisole & Closantel \\
\cline { 1 - 4 } A. oligospora & 0.5 & 4.0 & 0.125 & 0.234 & 0.312 \\
D. flagrans & 0.5 & 0.031 & 0.062 & 0.117 & 0.039 \\
P. lilacinus & 2.0 & 2.0 & 2.0 & 0.937 & 0.312 \\
\hline
\end{tabular}

systems (Larsen, 1999). The combined use of chemical and biological controls may be a viable strategy for livestock, cost reduction, resistance, toxicity and management, in addition to reducing residues in products of animal origin and in the environment (Soares and Monteiro, 2011).

According to Hirose et al. (2001), the use of chemicals which are incompatible with fungi can inhibit the development and reproduction of these microorganisms, thus affecting an effective biological control. This incompatibility has been reported by studies which have demonstrated the influence of chemicals on entomopathogenic fungus viability (Barci et al., 2009) although, in another study, the fungus and insecticide employees were considered compatible, allowing their joint use in controlling (Anhalt et al., 2010). Thereby, further studies to evaluate the alterations in nematophagous fungus development caused by the combined use with antiparasitic drugs are needed. In vivo assays performed by Sanyal et al. (2004), demonstrated that $D$. flagrans was inhibited when used in combination with albendazole. Similarly, Singh et al. (2010), upon analyzing the interaction of albendazole and triclabendazole with Paecilomyces lilacinus and Verticillium chlamydosporium showed that, when used in vivo, these anthelmintics had a negative impact on fungus viability. The in vitro results in this study are in agreement with those obtained by Sanyal et al. (2004) and Singh et al. (2010), showing that not only albendazole, but also thiabendazole, ivermectin, levamisole and closantel are able to inhibit the growth of the evaluated fungi. Although different fungus MICs were observed, D. flagrans showed the lowest MICs against all drugs tested. As this is one of the most effective predatory fungi against endoparasites (Braga et al., 2011; Sagüés et al., 2011), the results of this study demonstrate the importance of compatibility tests between anthelmintics and nematophagous fungi. On the other hand, the MICs obtained against ivermectin, employed both as an anthelmintic and in ruminant tick control, suggest that the compatibility of this chemical with other biological practices must be known so as to avoid loss of control efficiency.

In vitro test techniques that evaluate compatibility of chemicals with entomopathogenic fungi usually make use of different serial dilutions of the chemicals added to a culture medium, making the method both laborious and costly (Oliveira and Neves, 2004; Barci et al., 2009; Asi et al., 2010). This study, however, used the broth dilution method based on (CLSI - M38A). The technique adapted to parasitic drugs proved to be easy to use, fast, reproducible and safe, and can be routinely used in compatibility tests to anthelmintics.
Through the methodology used in the present study, it was concluded that all tested drugs showed inhibitory effect against the fungi used for biological control. Consequently, the results obtained allow previewing that the knowledge of chemical compatibility on fungus development is essential for the establishment of integrated control programs of animal parasitosis. Still, research works evaluating the drugs action against nematophagous fungi in vivo are necessary.

\section{Acknowledgements}

The authors would like to thank CAPES (Coordination of Improvement of Higher Education Personnel, Brazil) for its financial support.

\section{References}

ALIZADEH, A., SAMIH, M.A., KHEZRI, M. and RISEH, R.S., 2007. Compatibility of Beauveria bassiana (Bals.) Vuill. with several pesticides. International Journal of Agriculture and Biology, vol. 9, no. 1, pp. 31-34.

ANHALT, F.A., AZEVEDO, J.L., SUGAYAMA, R.L., SPECHT, A. and BARROS, N.M., 2010. Potential of Metarhizium anisopliae (Metsch.) Sorokin (Ascomycetes, hypocreales) in the control of Bonagota salubricola (Meyrick) (Lepidoptera, Tortricidae) and its compatibility with chemical insecticides. Brazilian Journal of Biology = Revista Brasileira de Biologia, vol. 70, no. 4, pp. 931-936. PMid:21180896.

ASI, M.R., BASHIR, M.H., AFZAL, M., ASHFAQ, M. and SAHI, S.T., 2010. Compatibility of entomopathogenic fungi, Metarhizium anisopliae and Paecilomyces fumosoroseus with selective insecticides. Pakistan Journal of Botany, vol. 42, no. 6, pp. 4207-4214.

BARCI, L.A.G., WENZEL, I.M., ALMEIDA, J.E.M., CAMPOS, A.H.C. and PRADO, A.P., 2009. Compatibilidade de isolados de Beauveria bassiana (Ascomycetes: Clavicipitaceae) com carrapaticidas químicos utilizados no controle do carrapato dos bovinos. Revista Brasileira de Parasitologia Veterinária, vol. 18, no. e1, suppl. 1, pp. 63-68. http://dx.doi.org/10.4322/ rbpv.018e1012. PMid:20040194.

BRAGA, F.R., ARAÚJO, J.M., SILVA, A.R., ARAÚJO, J.V., CARVALHO, R.O., TAVELA, A.O., SILVA, M.E., FERNANDES, F.M. and MELO, A.L., 2011. Destruição de larvas infectantes de Strongyloides venezuelensis pelos fungos Duddingtonia flagrans, Arthrobotrys robusta e Monacrosporium sinense. Revista da Sociedade Brasileira de Medicina Tropical, vol. 44, no. 3, pp. 389-391. PMid:21779680.

BRAGA, F.R., ARAÚJO, J.V., CAMPOS, A.K., CARVALHO, R.O., SILVA, A.R., TAVELA, A.O. and MACIEL, A.S., 2007. Observação in vitro da ação dos isolados fúngicos Duddingtonia flagrans, Monacrosporium thaumasium e Verticillium chlamydosporium sobre ovos de Ascaris lumbricoides (Lineu, 1758). Revista da 
Sociedade Brasileira de Medicina Tropical, vol. 40, no. 3, pp. 356-358. http://dx.doi.org/10.1590/S0037-86822007000300024. PMid:17653479.

BRAGA, F.R., ARAÚJO, J.V., CARVALHO, R.O., SILVA, A.R., ARAÚJO, J.M. and TAVELA, A.O., 2008. Observação in vitro da ação dos fungos nematófagos Duddingtonia flagrans, Monacrosporium thaumasium e Pochonia chlamydosporia sobre ovos de Eurytrema coelomaticum. Parasitologia Latinoamericana, vol. 63 , no. 1 , pp. $40-45$.

CARACOSTANTOGOLO, J., ANZIANI, O., ROMERO, J., SUÁREZ, V. and FIEL, C.A., 2013. Resistencia a los antihelmínticos en Argentina. In: C.A. FIEL and A. NARI, eds. Enfermedades parasitarias de importancia clínica y productiva en ruminates: fundamentos epidemiológicos para su diagnóstico y control. Montevideo: Editorial Hemisferio Sul, pp. 255-282.

CARVALHO, R.O., ARAÚJO, J.V., BRAGA, F.R., ARAÚJO, J.M., ALVES, C.D., 2010. Ovicidal activity of Pochonia chlamydosporia and Paecilomyces lilacinus on Toxocara canis eggs. Veterinary Parasitology, vol. 169, no. 1-2, pp. 123-127.

CEZAR, A.S., CATTO, J.B. and BIANCHIN, I., 2008. Controle alternativo de nematódeos gastrintestinais dos ruminantes: atualidade e perspectivas. Ciência Rural, vol. 38, no. 7, pp. 2083-2091. http:// dx.doi.org/10.1590/S0103-84782008000700048.

CHARLES, T.P., ROQUE, M.V.C. and SANTOS, C.P., 1996. Reduction of Haemonchus contortus infective larvae by Harposporium anguillulae in sheep faecal cultures. International Journal for Parasitology, vol. 26, no. 5, pp. 509-510. http://dx.doi. org/10.1016/0020-7519(96)00026-4. PMid:8818730.

CLINICAL AND LABORATORY STANDARDS INSTITUTE - CLSI, 2008. Reference method for broth dilution antifungal susceptibility testing of filamentous fungi. Approved standard Document M38-A2. Wayne: CLSI.

HIROSE, E., NEVES, P.M.O.J., ZEQUI, J.A.C., MARTINS, L.H., PERALTA, C.H. and MOINO JUNIOR, A., 2001. Effect of biofertilizers and neem oil on the entomopathogenic fungi Beauveria bassiana (Bals.) Vuill. and Metarhizium anisopliae (Metsch.) sorok. Brazilian Archives of Biology and Technology, vol. 44, no. 4, pp. 419-423. http://dx.doi.org/10.1590/S151689132001000400013 .

JANSSON, H.B., JEYAPRAKASH, A. and ZUCKERMAN, M.B., 1985. Differential adhesion and infection of nematodes by the endoparasitic fungus Meria coniospora (Deuteromycetes). Applied and Environmental Microbiology, vol. 49, no. 3, pp. 552-555. PMid:16346749.

LARSEN, M., 1999. Biological control of helminths. International Journal for Parasitology, vol. 29, no. 1, pp. 139-146, discussion 153-154. http://dx.doi.org/10.1016/S0020-7519(98)00185-4. PMid:10048826.

MOTA, M.A., CAMPOS, A.K. and ARAÚJO, J.V., 2003. Controle biológico de helmintos parasitos de animais: estágio atual e perspectivas futuras. Pesquisa Veterinaria Brasileira, vol. 23, no. 3, pp. 93-100. http://dx.doi.org/10.1590/S0100736X2003000300001.

NEVES, P.M.O.J., HIROSE, E., TCHUJO, P.T. and MOINO JUNIOR, A., 2001. Compatibility of Entomopathogenic Fungi with neonicotinoid insecticides. Neotropical Entomology, vol. 30, no. 2, pp. 263-268. http://dx.doi.org/10.1590/S1519566X2001000200009.

OLIVEIRA, R.C. and NEVES, P.M.O.J., 2004. Compatibility of Beauveria bassiana with acaricides. Neotropical Entomology, vol. 33, no. 3, pp. 353-358. http://dx.doi.org/10.1590/S1519566X2004000300013.

SAGÜÉS, M.F., FUSÉ, L.A., FERNÁNDEZ, A.S., IGLESIAS, L.E., MORENO, F.C. and SAUMELL, C.A., 2011. Efficacy of an energy block containing Duddingtonia flagrans in the control of gastrointestinal nematodes of sheep. Parasitology Research, vol. 109, no. 3, pp. 707-713. http://dx.doi.org/10.1007/s00436011-2302-y. PMid:21380576.

SANTOS, C.P. and CHARLES, T.P., 1995. Efeito da aplicação de conídios de Drechmeria coniospora em cultivos de fezes contendo ovos de Haemonchus contortus. Arquivo Brasileiro de Medicina Veterinária e Zootecnia, vol. 47, pp. 123-128.

SANYAL, P.K., CHAUHAN, J.B. and MUKHOPADHYAYA, P.N., 2004. Implications of fungicidal effects of benzimidazole compounds on Duddingtonia flagrans in integrated nematode parasite management in livestock. Veterinary Research Communications, vol. 28, no. 5, pp. 375-385. http://dx.doi. org/10.1023/B:VERC.0000034997.50332.77. PMid:15379432.

SAUMELL, C., FUSÉ, L., IGLESIAS, L., FERNÁNDEZ, S. and FIEL, C., 2008. Enfoque bioecológico del potencial de los hongos nematófagos en el control biológico de tricostrongilídeos de rumiantes. Revista de Medicina Veterinaria, vol. 89, no. 2, pp. 45-54.

SAUMELL, C.A., FERNÁNDEZ, A.S., FUSÉ, L.A., RODRÍGUEZ, M., SAGÜÉS, M.F. and IGLESIAS, L.E., 2015. Nematophagous fungi from decomposing cattle faeces in Argentina. Revista Iberoamericana de Micologia, vol. 32, no. 4, pp. 252-256. http:// dx.doi.org/10.1016/j.riam.2014.09.003. PMid:25766793.

SINGH, R.K., SANYAL, P.K., PATEL, N.K., SARKAR, A.K., SANTRA, A.K., PAL, S. and MANDAL, S.C., 2010. Fungusbenzimidazole interactions: a prerequisite to deploying egg-parasitic fungi Paecilomyces lilacinus and Verticillium chlamydosporium as biocontrol agents against fascioliasis and amphistomiasis in ruminant livestock. Journal of Helminthology, vol. 84, no. 2, pp. 123-131. http://dx.doi.org/10.1017/S0022149X09990344. PMid:19698195.

SOARES, F.B. and MONTEIRO, A.C., 2011. Compatibilidade de Metarhizium anisopliae com carrapaticidas químicos. Arquivos do Instituto Biologico, vol. 78, no. 3, pp. 385-391. 